\title{
Pulmonary apical fibrosis in a patient treated earlier for breast cancer
}

\author{
Rajeev Kumar Seam, ${ }^{1}$ Swaroop Revannasiddaiah, ${ }^{2}$ Bhaskar Bhardwaj, ${ }^{3}$ \\ Manoj Kumar Gupta ${ }^{1}$
}

'Department of Radiation Oncology, Regional Cancer Centre, Indira Gandhi Medical College, Shimla, Himachal Pradesh, India

${ }^{2}$ Department of Radiation Oncology, Swami Rama Cancer Hospital \& Research Institute, Haldwani, Uttarakhand, India ${ }^{3}$ Department of Cardiology, Indira Gandhi Medical College, Shimla, Himachal Pradesh, India

\section{Correspondence to} Dr Swaroop Revannasiddaiah, swarooptheone@gmail.com

\begin{tabular}{|l|}
\hline To cite: Seam RK, \\
Revannasiddaiah S, \\
Bhardwaj B, et al. BMJ Case \\
Rep Published online: \\
[please include Day Month \\
Year] doi:10.1136/bcr-2013- \\
201366 \\
\hline
\end{tabular}

\section{DESCRIPTION}

A 46-year-old woman who completed 10 years of follow-up after successful treatment for right-sided breast cancer presented in peak winter with discomforts of cough and accompanying chest-wall musculoskeletal pain persisting for 4 days. She had earlier received multimodality therapy with surgery (modified radical mastectomy), radiotherapy (to the ipsilateral postmastectomy chest wall, axilla and the supraclavicular area), chemotherapy and hormonal therapy.

A chest radiograph demonstrated right pulmonary apical fibrosis (figure 1). A CT scan demonstrated a band which showed no contrast enhancement (figure 2). There were no cavitations or calcifications. The rest of the lungs and the mediastinum were unremarkable. A workup on the lines of tuberculosis was negative (negative sputum-smear examination and the Mantoux test yielded an induration of $3 \mathrm{~mm}$ diameter). There were no histories or clinical features suggestive of rheumatological disorders.

In the meantime, the patient's cough and chest pain subsided with symptomatic treatment. However, a fine-needle aspirate (resorted to allay patient anxiety) was non-specific, with occasional histiocytes found amidst a predominantly fibrotic background. The diagnosis was assigned as postradiation pulmonary fibrosis.

Radiotherapy after mastectomy involves irradiation of the chest wall with tangential beam placements placed at angles so as to irradiate the chest wall while sparing the underlying lung and the heart. ${ }^{1}$ Irradiation of the supraclavicular nodal

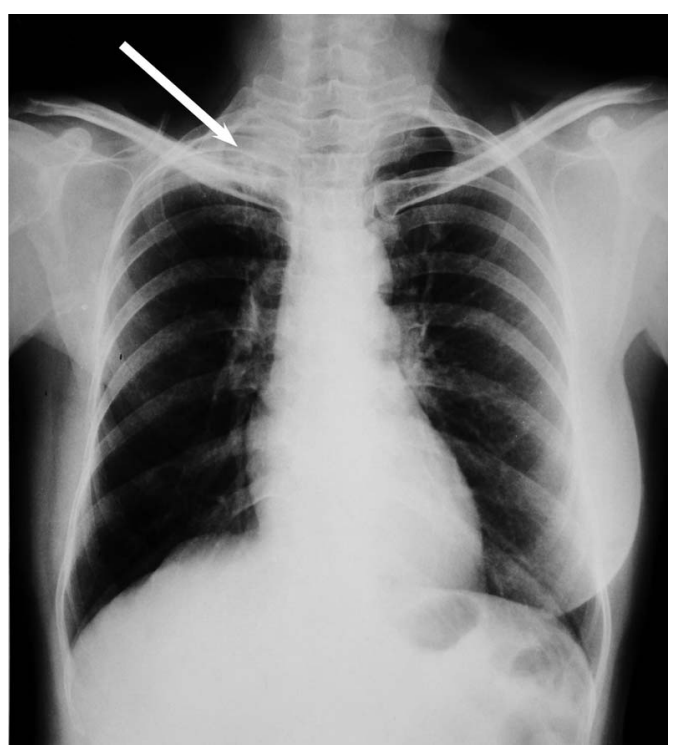

Figure 1 Chest radiograph depicting the presence of a right-sided apical fibrosis with an ipsilateral lack of the mammary shadow.

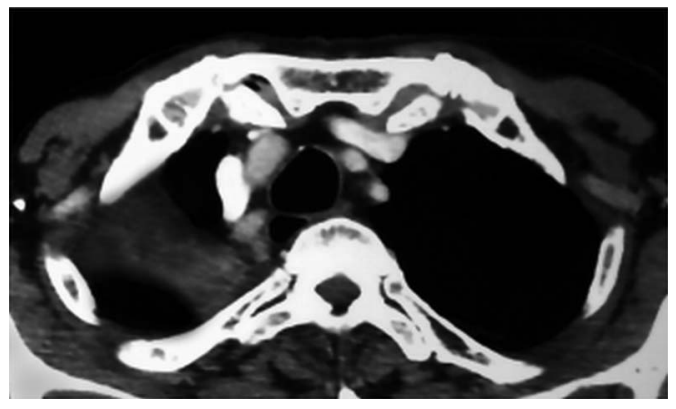

Figure 2 Band-like fibrosis in the right pulmonary apex visualised in a CT section.

region is usually considered to be indicated in patients with involvement of more than three axillary nodes or with involved supraclavicular nodes. This requires the placement of a direct supraclavicular field, through which the radiation beam passes perpendicularly onto the supraclavicular fossa. Thus, a significant radiation dose can be expected to reach the underlying pulmonary apex. ${ }^{1}$

Radiation induced injury to the lung in general is of two temporal types. An early transient stage of pneumonitis can set in at 4-6 weeks, which even if symptomatic, is mostly self-limiting. Later, a chronic fibrotic stage in observed as late as 624 months after irradiation. The factors that decide the onset and extent of injury include the total radiation dose, dose fractionation and also possibly the use of chemotherapy. ${ }^{2}$

Radiation-induced pulmonary fibrosis must be given due consideration as a possible diagnosis during the evaluation of pulmonary apical radiological opacities in the ever-growing population of breast cancer survivors. ${ }^{3}$

\section{Learning points}

- After mastectomy, radiotherapy to the chest wall is typically delivered by the use of tangential beam placements, which spares the underlying lungs.

- However, the irradiation of the supraclavicular and level III axillary areas require the use of a direct field placement, which can cause radiation-induced changes in the apex of the ipsilateral lung.

- The possibility of prior irradiation as an aetiology should be acknowledged in the differential diagnosis of pulmonary apical fibrosis in the ever-growing population of breast cancer survivors. 
Contributors SR prepared the drawings and provided the radiographs. MKG wrote the initial manuscript. RKS prepared the final version of the manuscript. BB prepared the quiz and the multiple choice questions.

Competing interests None.

Patient consent Obtained.

Provenance and peer review Not commissioned; externally peer reviewed.

\section{REFERENCES}

1 Lingos TI, Recht A, Vicini F, et al. Radiation pneumonitis in breast cancer patients treated with conservative surgery and radiation therapy. Int I Radiat Oncol Biol Phys 1991;21:355-60.
2 Davis SD, Yankelevitz DF, Henschke Cl. Radiation effects on the lung: clinical features, pathology, and imaging findings. AJR Am J Roentgenol 1992;159:1157-64.

3 Rothwell Rl, Kelly SA, Joslin CA. Radiation pneumonitis in patients treated for breast cancer. Radiother Oncol 1985;4:9-14.

4 Jung Jl, Kim HH, Park SH, et al. Thoracic manifestations of breast cancer and its therapy. Radiographics 2004;24:1269-85.

Copyright 2013 BMJ Publishing Group. All rights reserved. For permission to reuse any of this content visit http://group.bmj.com/group/rights-licensing/permissions.

BMJ Case Report Fellows may re-use this article for personal use and teaching without any further permission.

Become a Fellow of BMJ Case Reports today and you can:

- Submit as many cases as you like

- Enjoy fast sympathetic peer review and rapid publication of accepted articles

- Access all the published articles

- Re-use any of the published material for personal use and teaching without further permission

For information on Institutional Fellowships contact consortiasales@bmjgroup.com

Visit casereports.bmj.com for more articles like this and to become a Fellow 